\title{
ANALISIS PERBANDINGAN KINERJA ALGORITMA FIXED LENGTH BINARY ENCODING DAN ALGORITMA ELIAS GAMMA CODE DALAM KOMPRESI FILE TEKS
}

\author{
Dian Pratiwi ${ }^{1}$, Taronisokhi Zebua ${ }^{2}$ \\ ${ }^{1}$ Program Studi Teknik Informatika STMIK Budi Darma, Medan, Indonesia \\ ${ }^{2}$ Program Studi Teknik Informatika AMIK Stiekom Sumatera Utara, Rantau Parapat, Indonesia \\ Email: ${ }^{1}$ dianpratiwi0497@gmail.com, ${ }^{2}$ taronizeb@gmail.com
}

\begin{abstract}
Abstrak
Saat ini, ada banyak algoritma yang dikembangkan untuk kompresi data, namun belum ada yang baik untuk mengkompresi berbagai tipe file karena karekteristik atau struktur file yang berbeda-beda. Penelitian ini menguraikan hasil perbandingan antara dua algoritma kompresi dengan tujuan agar dapat diketahui kinerja antara algoritma Fixed Length Binary Encoding (FLBE) dan algoritma elias gamma code dalam melakukan kompresi file teks khususnya file teks yang berformat rtf. Parameter yang dibandingkan adalah ratio of compression, compression ratio, redudancy dan time. Berdasarkan hasil pengujian menunjukan bahwa algoritma fixed length binary encoding lebih baik dari pada algoritma elias gamma code dimana rata-rata hasil perbandingan ratio of compression algoritma fixed length binary encoding sebesar 1,66 bit sedangkan elias gamma code sebesar 1,62 bit. Ratarata compression ratio algoritma fixed length binary encoding sebesar 60,9\% sedangkan Elias Gamma Code sebesar 62,20\%. Nilai rata-rata redudancy algoritma fixed length binary encoding sebesar 39,1\% sedangkan elias gamma code sebesar 37,79\%. Nilai ratarata Time kompresi algoritma fixed length binary encoding sebesar 16 ms sedangkan elias gamma code sebesar $21 \mathrm{~ms}$.
\end{abstract}

Kata Kunci: Perbandingan, Kompresi, algoritma FLBE, Elias Gamma Code, File Teks, rtf

\begin{abstract}
Now days, there are many algorithms developed for data compression, but there is no one that is good for compressing various types of files because of different characteristics or file structures. This research explained the result of two compression algorithms in order to know the performance comparison between the Fixed Length Binary Encoding (FLBE) algorithm and the elias gamma code algorithm in compressing text files, especially in format rtf. The parameters being compared are the ratio of compression, compression ratio, redundancy and time. Based on the test results show that the fixed length binary encoding algorithm is better than the elias gamma code algorithm where the average ratio of compression results of fixed length binary encoding algorithm is 1.66 bits while the elias gamma code is 1.62 bits. The average compression ratio of fixed length binary encoding algorithm is $60.9 \%$ while Elias Gamma Code is $62.20 \%$. The average value of the redundancy of the fixed length binary encoding algorithm is $39.1 \%$ while the gamma code elias is $37.79 \%$. The average time compression value of the fixed length binary encoding algorithm is $16 \mathrm{~ms}$ while the elias gamma code is $21 \mathrm{~ms}$.
\end{abstract}

Keywords: comparison, compression, FLBE algorithm, Elias Gamma Code Algorithm, text, rtf

\section{PENDAHULUAN}

Kecenderungan manusia dalam mengumpulkan data berupa dokumen dan file teks menyebabkan pengguna membutuhkan media penyimpanan yang besar. Teknik kompresi pada saat ini menjadi salah sastu solusi dalam pemampatan file yang berukuran besar. Banyaknya algoritma kompresi yang dapat digunakan dalam mengkompresi file teks, namun masing-masing algoritma memiliki kelebihan dan kekurangan dalam hal pengukuran kinerjanya. Performa algoritma kompresi dapat diketahui dengan melakukan perhitungan kinerjanya dengan parameter kompresi. Tidak semua hasil pemampatan menjadi sangat kecil, bisa saja hanya berkurang sedikit saja, hal itu tergantung dari algoritma yang digunakan. Pemilihan algoritma yang sesuai sangat diperlukan dari beberapa faktor yang menjadi pertimbangan yaitu rasio perbandingan waktu yang dibutuhkan dalam kompresi, waktu dekompresi dan file hasil kompresi [1]. Faktor yang menjadi pertimbangan dalam menentukan suatu metode kompresi yang tepat, yaitu dalam sumber daya yang dibutuhkan (kecepatan PC, memori), kecepatan kompresi, besarnya redundansi, kompleksitas algoritma dan ukuran file hasil kompresi [2]. Dalam membandingkan algoritma kompresi dibutuhkan parameter untuk mengukur kinerja kompresi seperti Ratio Of Compression (RC), Compression Ratio (CR), Redundancy (Rd) dan Time. Penelitian ini menguraikan hasil melakukan pengukuran kinerja dari dua algoritma teknik kompresi yaitu algoritma Fixed Length Binary Encoding (FLBE) dan algoritma elias gamma code. Perbandingan dilakukan dengan mengukur nilai Ratio Of Compression (RC), Compression Ratio (CR), Redundancy (Rd) dan Time antara kedua algoritma tersebut, sehingga dapat diketahui algoritma yang memiliki kinerja yang lebih baik.

\section{TEORI}

\subsection{Teknik Kompresi}

Kompresi merupakan proses atau teknik memperkecil dan mengubah aliran data input menjadi aliran data baru yang memiliki ukuran lebih kecil, aliran tersebut berupa file atau buffer dalam memori [3]. Data kompresi merupakan 
proses mengkonversikan sebuah input data stream. Beberapa faktor yang biasa digunakan untuk menganalisa kualitas dari suatu teknik kompresi data [4], yaitu :

1. Ratio of Compression $\left(R_{C}\right)$, merupakan nilai perbandingan antara ukuran bit data sebelum dikompresi dengan ukuran bit data yang telah dikompresi.

$R_{C}=\frac{\text { Ukuran bit data sebelum dikompresi }}{\text { Ukuran bit data setelah dikompresi }}$

2. Compression Ratio $\left(C_{R}\right)$, merupakan persentase perbandingan antara data yang sudah dikompresi dengan data yang belum dikompresi.

$C_{R}=\frac{\text { Ukuran bit data setelah dikompresi }}{\text { Ukuran bit data sebelum dikompresi }} \times 100 \%$

3. Redudancy (Rd), merupakan persentasi dari hasil selisih antara ukuran data sebelum dikompresi dengan data setelah dikompresi.

$R d=100 \%-C_{R}$

\subsection{Algoritma Fixed Length Binary Encoding (FLBE)}

Algoritma Fixed Length Binary Encoding (FLBE) melakukan pengkodean setiap karakter dengan kode biner yang panjang karakternya diperoleh berdasarkan jumlah frekuensi kemunculan dari masing-masing karakter. Karakter yang memiliki kemuculan sering akan memiliki frekuensi kode biner lebih sedikit dibandingkan dengan karakter yang frekuensi nya jarang muncul. Algoritma ini, bekerja dengan merubah simbol asli ke dalam bentuk fixed-length code. Proses kompresi pada algoritma FLBE akan berhenti jika panjang bit karakternya mencapai jumlah karakter yang terakhir. Kemudahan tersebut berbanding lurus dengan proses mengubah kembali fixed-length code menjadi simbol aslinya, sehingga algoritma ini cukup baik dalam mengkompresi file teks [3].

FLBE akan mengambil karakter yang terdapat dalam string yang ingin dikompresi, kemudian menghitung frekuensi (jumlah kemunculan karakter pada string). FLBE mengubah bit karakter menjadi fixed-length code sehingga menghasilkan string bit yang baru. String bit inilah yang merupakan hasil kompresi dari algoritma FLBE. Pada algoritma ini terdapat dua proses utama yaitu proses kompresi dan dekompresi. Langkah-langkah kompresi dari algoritma Fixed Length Binary Encoding (FLBE) [3], yaitu :

1. String yang akan dikompresi disusun kedalam tabel sesuai dengan urutan frekuensi kemunculan karakter pada string.

2. Setelah semua karakter tersusun, kemudian pada setiap karakter diberi nilai biner mulai dari 0 hingga biner ke $\mathrm{n}$ disesuaikan dengan posisi karakter terakhir. Setiap string berukuran 5 bit sehingga biner dengan nilai bit kurang dari 5 ditambahkan angka 0 disebelah kiri hingga mencapai 5 bit yang akan menjadi kode FLBE.

3. Langkah selanjutnya adalah menyusun kembali kode FLBE yang diperoleh ke dalam tabel sesuai dengan posisi karakter pada string.

4. Gabungkan semua string bit yang diperoleh.

\subsection{Algoritma Elias Gamma Code}

Algoritma elias gamma memiliki proses kompresi dan dekompresi cukup cepat karena algoritma elias gamma melakukan proses encoding pada saat proses kompresi berlangung. Waktu kompresi tidak bergantung pada besarnya ukuran file dan waktu dekompresi tidak tergantung pada waktu kompresi. Waktu kompresi rata-rata menbutuhkan waktu lebih dari pada waktu dekompresi [5]. Elias menambah panjang dalam unary (u) untuk membentuk tabel kode elias gamma. Dalam kode berikutnya, E $\gamma$ ditambahkan pada panjang kode $(\mathrm{M})$ dalam biner $(\beta)$. Dengan demikian elias gamma code, yang juga untuk bilangan bulat positif, sedikit lebih kompleks untuk dibangun [6].

Adapun aturan untuk mengkodekan sebuah bilangan dengan mengunakan Elias Gamma Code [6] adalah sebagai berikut:

1. Temukan bilangan bulat $\mathrm{N}$ terbesar sehingga $2^{N} \leq n<2^{N+1}$ dan tulis $n=2^{N}+L$.

2. Rubah nilai $\mathrm{n}$ menjadi bilangan biner, lalu hilangkan 1 bit paling kiri.

3. Kodekan $\mathrm{N}$ dalam bentuk unary sebagai $\mathrm{N}$ nol diikuti oleh 1 atau $\mathrm{N} 1$ diikuti oleh 0.

4. Tambahkan sisa digit biner $\mathrm{n}$ dibelakang kode unary yang telah dihasilkan.

Sebagai contoh diambil sebuah $\mathrm{n}=1$. Lalu temukan bilangan bulat $\mathrm{N}$ terbesar sehingga $2^{N} \leq n<2^{N+1}=$ $2^{0} \leq 1<2^{0+1}$. Setelah ditemukan bilangan $\mathrm{N}$ terbesar lalu rubah nilai $\mathrm{n}$ menjadi bilangan biner adalah $\beta(1)=1$, lalu hilangkan 1 bit paling kiri $\beta(1)=1 \rightarrow$ habis. Kodekan $\mathrm{N}$ dalam bentuk unary sebagai 0 diikuti oleh 1 sehingga dihasilakan unary $\mathrm{N}=0 \rightarrow 1$. Kemudian tambahkan sisa digit biner $\mathrm{n}$ dibelakang kode unary yang telah dihasilkan adalah 1.

\section{ANALISA DAN PEMBAHASAN}

Algoritma dalam teknik kompresi saat ini telah banyak dikembangkan dan diperlukan terutama untuk data-data yang berukuran besar. Namun masing-masing algoritma tersebut memilliki kelemahan dan kelebihan terutama terhadap performanya dalam melakukan proses kompresi maupun hasil kompresinya. Informasi mengenai tingkat performa dari algoritma sangat diperlukan agar dapat hasil kompresi yang didapatkan lebih baik. Algoritma Fixed 
Length Binary Encoding (FLBE) dan elias gamma code merupakan algoritma yang sangat umum digunakan dalam proses kompresi file. Agar performa dari keduanya dapat diketahui, maka perlu dilakukan perbandingan performa antara keduanya. Penelitian ini menguraikan hasil perbandingan kinerja dari kedua algoritma ini yang diukur berdasarkan parameter nilai Ratio Of Compression (RC), Compression Ratio (CR), Redundancy (Rd) dan Time terhadap file teks berformat rtf.

File teks rtf yang digunakan dalam penelitian ini sebagai sampel adalah file teks yang berukuran asli sebesar $30.4 \mathrm{~KB}$ (31.219 bytes). Agar proses yang dilakukan lebih sederhana, maka diambil sample teks sebesar 50 karakter yang terdiri atas 50 bytes, setiap bytes terdiri dari 8 bit. Dengan demikian dapat dihitung jumlah bit yang akan diproses adalah $50 \times 8$ bit atau sebanyak 400 bit. Apabila diubah kedalam satuan bytes menjadi 400/8 = 50 bytes. Berikut ini teks sample teks dari file rtf "NAMA SAYA DIAN PRATIWI SAYA TINGGAL DI LUBUK PAKAM". Ukuran string dari teks sampel di atas disajikan pada tabel 1 di bawah ini.

Tabel 1. Ukuran String Sebelum Dikompresi

\begin{tabular}{|c|c|c|c|c|c|}
\hline Karakter & Frekuensi & ASCII Desimal & ASCII Binari & Bit & Bit $\times$ Frekuensi \\
\hline $\mathrm{N}$ & 3 & 78 & 01001110 & 8 & 24 \\
\hline A & 11 & 65 & 01000001 & 8 & 88 \\
\hline M & 2 & 77 & 01001101 & 8 & 16 \\
\hline Spasi & 8 & 32 & 00100000 & 8 & 64 \\
\hline $\mathrm{S}$ & 2 & 83 & 01010011 & 8 & 16 \\
\hline $\mathrm{Y}$ & 2 & 89 & 01011001 & 8 & 16 \\
\hline $\mathrm{D}$ & 2 & 68 & 01000100 & 8 & 16 \\
\hline I & 5 & 73 & 01001001 & 8 & 40 \\
\hline $\mathrm{P}$ & 2 & 80 & 01010000 & 8 & 16 \\
\hline $\mathrm{R}$ & 1 & 82 & 01010010 & 8 & 8 \\
\hline $\mathrm{T}$ & 2 & 84 & 01010100 & 8 & 16 \\
\hline W & 1 & 87 & 01010111 & 8 & 8 \\
\hline G & 2 & 71 & 01000111 & 8 & 16 \\
\hline $\mathrm{L}$ & 2 & 76 & 01001100 & 8 & 16 \\
\hline $\mathrm{U}$ & 2 & 85 & 01010101 & 8 & 16 \\
\hline B & 1 & 66 & 01000010 & 8 & 8 \\
\hline $\mathrm{K}$ & 2 & 75 & 01001011 & 8 & 16 \\
\hline \multicolumn{5}{|c|}{ Jumlah Bit $\times$ Frekuensi } & 400 Bit \\
\hline
\end{tabular}

\subsection{Kompresi Berdasarkan Algoritma Fixed Length Binary Encoding}

Berdasarkan langkah-langkah algoritma fixed length binary encoding dalam mengkompresi data, maka dilakukan proses penyusunan frekuensi kemunculan dari karakter data yang akan dikompresi, kemudian masingmasing karakter pada susunan tersebut diberi nilai biner mulai dari 0 hingga nilai biner ke $n$ untuk mendapatkan kode FLBE. Kode yang diperoleh akan disusun kembali sesuai dengan posisi karakter pada string. Gabungan dari kode FLBE yang telah disusun ini merupakan hasil dari kompresi. Prosesnya disajikan pada tabel 2 berikut ini.

Tabel 2. Penggantian Karakter Dengan Kode Fixed Length Binary Encoding

\begin{tabular}{|c|c|c|c|c|c|}
\hline No & Karakter & Frekuensi & FLBE Code & Bit & Bit $\times$ Frekuensi \\
\hline 0 & $\mathrm{~A}$ & 11 & 00000 & 5 & 55 \\
\hline 1 & Spasi & 8 & 00001 & 5 & 40 \\
\hline 2 & I & 5 & 00010 & 5 & 25 \\
\hline 3 & $\mathrm{~N}$ & 3 & 00011 & 5 & 15 \\
\hline 4 & M & 2 & 00100 & 5 & 10 \\
\hline 5 & $\mathrm{~S}$ & 2 & 00101 & 5 & 10 \\
\hline 6 & Y & 2 & 00110 & 5 & 10 \\
\hline 7 & D & 2 & 00111 & 5 & 10 \\
\hline 8 & $\mathrm{P}$ & 2 & 01000 & 5 & 10 \\
\hline 9 & $\mathrm{~T}$ & 2 & 01001 & 5 & 10 \\
\hline 10 & $\mathrm{G}$ & 2 & 01010 & 5 & 10 \\
\hline 11 & $\mathrm{~L}$ & 2 & 01011 & 5 & 10 \\
\hline 12 & $\mathrm{U}$ & 2 & 01100 & 5 & 10 \\
\hline 13 & $\mathrm{~K}$ & 2 & 01101 & 5 & 10 \\
\hline 14 & $\mathrm{R}$ & 1 & 01110 & 5 & 5 \\
\hline 15 & W & 1 & 01111 & 5 & 5 \\
\hline
\end{tabular}




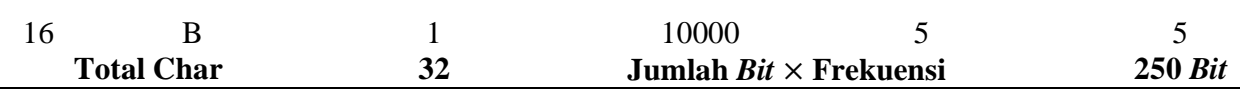

Tahap selanjutnya adalah menyusun kembali kode-kode FLBE (tabel 1) sesuai dengan posisi karakter pada string, hasilnya seperti di bawah ini.

$\begin{array}{cccccccccc}\text { N } & \text { A } & \text { M } & \text { A } & \text { Spasi } & \text { S } & \text { A } & \text { Y } & \text { A } & \text { Spasi } \\ 00011 & 00000 & 00100 & 00000 & 00001 & 00101 & 00000 & 00110 & 00000 & 00001 \\ \text { D } & \text { I } & \text { A } & \text { N } & \text { Spasi } & \text { P } & \text { R } & \text { A } & \text { T } & \text { I } \\ 00111 & 00010 & 00000 & 00011 & 00001 & 01000 & 01110 & 00000 & 01001 & 00010 \\ \text { W } & \text { I } & \text { Spasi } & \text { S } & \text { A } & \text { Y } & \text { A } & \text { Spasi } & \text { T } & \text { I } \\ 01111 & 00010 & 00001 & 00101 & 00000 & 00110 & 00000 & 00001 & 01001 & 00010 \\ \text { N } & \text { G } & \text { G } & \text { A } & \text { L } & \text { Spasi } & \text { D } & \text { I } & \text { Spasi } & \text { L } \\ 00011 & 01010 & 01010 & 00000 & 01011 & 00001 & 00111 & 00010 & 00001 & 01011 \\ \text { U } & \text { B } & \text { U } & \text { K } & \text { Spasi } & \text { P } & \text { A } & \text { K } & \text { A } & \text { M } \\ 01100 & 10000 & 01100 & 01101 & 00001 & 01000 & 00000 & 01101 & 00000 & 00100\end{array}$

Biner-biner dari masing-masing karakter digabungkan, sehingga diperoleh biner-biner berikut ini :

00011000000010000000000010010100000001100000000001001110001000000000110000101000011100000001001 00010011110001000001001010000000110000000000101001000100001101010010100000001011000010011100010 000010101101100100000110001101000010100000000011010000000100

Sebelum didapatkan hasil akhir kompresi, maka dilakukan penambahan string bit yaitu padding bit dan flagging bit dengan ketentuan bila sisa hail bagi panjang string bit (hasil gabungan kode FLBE) terhadap 8 adalah n(1,2,3,4,5,6,7) maka tambahkan 0 sebanyak $7-n+$ "1" di akhir string bit. Nyatakan dengan L. Lalu tambahkan bilangan biner dari 9 - n. Nyatakan dengan bit akhir. Total panjang bit keseluruhan setelah ada penambahan bit adalah 250 bit +6 bit +8 bit $=264$ bit. Biner-biner inilah yang akan dijadikan sebagai hasil proses kompresi dan disimpan di media penyimpanan dengan format (*.flbe). Total bit yang diperoleh adalah sebanyak 264 bit atau bila dikonferis ke karakter akan menghasilkan 33 karakter.

Pengukuran kinerja dari algortima FLBE terhadap proses kompresi dapat dilakukan dengan menghitung nilai aspek berikut ini:

1. Ratio of Compression $\left(R_{C}\right)$

$$
R_{C}=\frac{\text { Ukuran bit data sebelum dikompresi }}{\text { Ukuran bit data setelah dikompresi }}=\frac{400 \mathrm{bit}}{264 \text { bit }}=1,5 \mathrm{bit}
$$

2. Compression Ratio $\left(C_{R}\right)$

$$
\begin{aligned}
& C_{R}=\frac{\text { Ukuran bit data setelah dikompresi }}{\text { Ukuran bit data sebelum dikompresi }} \times 100 \%=\frac{264}{400} \times 100 \% \\
& C_{R}=66 \%
\end{aligned}
$$

3. Redudancy $(\mathrm{Rd})$

$R d=100 \%-C_{R}=100 \%-66 \%=34 \%$

\subsection{Kompresi Berdasarkan Algoritma Elias Gamma Code}

Berikut ini adalah proses kompresi string sampel dalam penelitian ini berdasarkan algoritma elias gamma code. Proses kompresi dilakukan berdasarkan langkah-langkah pada teoritis algoritma ini.

Tabel 3. Pergantian Karakter Dengan Kode Elias Gamma Code

\begin{tabular}{cccccc}
\hline No & Karakter & Frekuensi & Elias Gamma Code & Bit & Bit $\times$ Frekuensi \\
\hline 1 & A & 11 & 1 & 1 & 11 \\
2 & Spasi & 8 & 010 & 3 & 24 \\
3 & I & 5 & 011 & 3 & 15 \\
4 & N & 3 & 00100 & 5 & 15 \\
5 & M & 2 & 00101 & 5 & 10 \\
6 & S & 2 & 00110 & 5 & 10 \\
7 & Y & 2 & 00111 & 5 & 10 \\
8 & D & 2 & 0001000 & 7 & 14 \\
9 & P & 2 & 0001001 & 7 & 14 \\
10 & T & 2 & 0001010 & 7 & 14 \\
11 & G & 2 & 0001011 & 7 & 14 \\
\hline
\end{tabular}




\begin{tabular}{lcclcc}
\hline 12 & $\mathrm{~L}$ & 2 & 0001100 & 7 & 14 \\
13 & $\mathrm{U}$ & 2 & 0001101 & 7 & 14 \\
14 & $\mathrm{~K}$ & 2 & 0001110 & 7 & 14 \\
15 & $\mathrm{R}$ & 1 & 0001111 & 7 & 7 \\
16 & $\mathrm{~W}$ & 1 & 000010000 & 9 & 9 \\
17 & $\mathrm{~B}$ & 1 & 000010001 & 9 & 9 \\
\hline \multicolumn{2}{r}{ Total Char } & $\mathbf{5 0}$ & Jumlah Bit $\times$ Frekuensi & $\mathbf{2 1 8}$ Bit \\
\hline
\end{tabular}

Tahap selanjutnya adalah menyusun kembali kode-kode yang telah dibuat pada tabel 3 di atas sesuai dengan posisi karakter pada string. Hasilnya seperti di bawah ini :

$\begin{array}{ccccccccccc}\text { N } & \text { A } & \text { M } & \text { A } & \text { Spasi } & \text { S } & \text { A } & \text { Y } & \text { A } & \text { Spasi } \\ 00100 & 1 & 00101 & 1 & 010 & 00110 & 1 & 00111 & 1 & 010 \\ \text { D } & \text { I } & \text { A } & \text { N } & \text { Spasi } & \text { P } & \text { R } & \text { A } & \text { T } & \text { I } \\ 0001000 & 011 & 1 & 00100 & 010 & 0001001 & 0001111 & 1 & 0001010 & 011 \\ \text { W } & & \text { I } & \text { Spasi } & \text { S } & \text { A } & \text { Y } & \text { A } & \text { Spasi } & \text { T } & \text { I } \\ 000010000 & 011 & 010 & 00110 & 1 & 00111 & 1 & 010 & 0001010 & 011 \\ \text { N } & \text { G } & \text { G } & \text { A } & \text { L } & \text { Spasi } & \text { D } & \text { I } & \text { Spasi } & \text { L } \\ 00100 & 0001011 & 0001011 & 1 & 0001100 & 010 & 0001000 & 011 & 010 & 0001100 \\ \text { U } & & \text { B } & \text { U } & \text { K } & \text { Spasi } & \text { P } & \text { A } & \text { K } & \text { A } & \text { M } \\ 0001101 & 000010001 & 0001101 & 0001110 & 010 & 0001001 & 1 & 0001110 & 1 & 00101\end{array}$

Sehingga diperoleh string bit sebagai berikut :

00100100101101000110100111101000010000111001000100001001000111110001010011000010000011010001101 00111101000010100110010000010110001011100011000100001000011010000110000011010000100010001101000 1110010000100110001110100101

Sebelum didapatkan hasil akhir dari proses kompresi, maka dilakukan penambahan string bit itu sendiri yaitu padding bit dan flagging bit. Bila sisa hasil bagi panjang string bit (hasil gabungan elias gamma code) terhadap 8 adalah n(1,2,3,4,5,6,7) maka tambahkan 0 sebanyak $7-n+$ "1" di akhir string bit. Nyatakan dengan L. Lalu tambahkan bilangan biner dari $9-\mathrm{n}$. Nyatakan dengan bit akhir. Total panjang bit keseluruhan setelah ada penambahan bit adalah 218 bit +6 bit +8 bit $=232$ bit. Biner-biner inilah yang dijadikan sebagai hasil kompresi berdasarkan algoritma elias gamma code, kemudian disimpan di media penyimpanan dengan format (*.egc). Total bit yang diperoleh adalah sebanyak 232 bit atau bila dionversi ke karakter akan menghasilkan 29 karakter.

Pengukuran kinerja dari algortima elias gamma code terhadap proses kompresi dapat dilakukan dengan menghitung nilai aspek berikut ini:

1. Ratio of Compression $\left(R_{C}\right)$

$R_{C}=\frac{\text { Ukuran bit data sebelum dikompresi }}{\text { Ukuran bit data setelah dikompresi }}=\frac{400 \mathrm{bit}}{232 \mathrm{bit}}=1,7 \mathrm{bit}$

2. Compression Ratio $\left(C_{R}\right)$

$C_{R}=\frac{\text { Ukuran bit data setelah dikompresi }}{\text { Ukuran bit data sebelum dikompresi }} \times 100 \%=\frac{232}{400} \times 100 \%$

$C_{R}=58 \%$

3. Redudancy $(\mathrm{Rd})$

$R d=100 \%-C_{R}=100 \%-58 \%=42 \%$

\subsection{Proses Dekompresi Berdasarkan Algoritma Fixed Length Binary Encoding}

Total panjang string bit (264 bit) terkompresi dikurangi total jumlah panjang padding dan flagging, dari string bit diatas terdapat padding sebanyak 6 bit dan flagging sebanyak 8 bit yang terdiri dari biner 7 (00000111), maka desimal $n=7$. Hilangkan bit pada bagian akhir sebanyak $7+7=14$. Berdasarkan perhitungan tersebut, maka diperoleh Nilai panjang string bit yang harus dibaca adalah $264-14=250$ bit, berarti jumlah bit-nya sama dengan jumlah bit file yang terkompresi menggunakan algoritma Fixed Length Binary Encoding.

Langkah selanjutnya adalah dengan menggantikan kode pada string bit berdasarkan kode Fixed Length Binary Encoding (FLBE) agar diperoleh isi file teks (*.rtf) seperti sebelum mengalami kompresi. Pembacaan String Bit dilakukan dari indeks terkecil sampai indeks terakhir dengan terus menambahkan nilai pada indeks sebelumnya yang terdapat pada kode Fixed Length Binary Encoding (FLBE). Indeks ke 1 adalah 0, tidak terdapat dalam tabel 3.3, indeks ke 2 adalah 00, tidak terdapat di dalam tabel 2, indeks ke 3 adalah 000, tidak terdapat pada tabel 2, indeks 4 adalah 0001, tidak terdapat pada tabel 2, indeks 5 adalah 00011 terdapat di dalam tabel 2 dan didapatkan bahwa biner 00011 adalah kode karakter N. Proses yang sama dilakukan untuk mendapatkan karakter selanjutnya. 


\subsection{Proses Dekompresi Berdasarkan Algoritma Elias Gamma Code}

Total panjang string bit (232 bit) terkompresi dikurangi total jumlah panjang padding dan flagging, dari string bit diatas terdapat padding sebanyak 6 bit dan flagging sebanyak 8 bit yang terdiri dari biner 7 (00000111), maka desimal $\mathrm{n}=7$. Hilangkan bit pada bagian akhir sebanyak $7+7=14$. Maka diperoleh nilai panjang string bit yang harus dibaca adalah $232-14=218$ bit, berarti jumlah bitnya sama dengan jumlah bit file yang terkompresi menggunakan algoritma Elias Gamma Code.

Proses selanjutnya adalah menggantikan kode pada string bit berdasarkan kode elias gamma code agar diperoleh isi file teks (*.rtf). Pembacaan string bit dilakukan dari awal hingga ditemukan kode 1. Catat posisi pertama atau urutan angka 1 dan nyatakan sebagai p sehingga bila berdasarkan posisi biner hasil kompresi, maka didapatkan nilai $\mathrm{p}=3$. Apabila ada angka 0 sebelum angka 1 nyatakan jumlah 0 dengan $\mathrm{n}$ sehingga $\mathrm{n}=2$, lanjutkan pembacaan

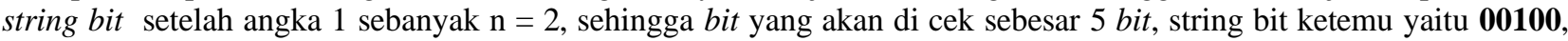
ganti kode hasil pembacaaan dengan karakter yang terdapat pada tabel 3. Proses pencarian kode bit berikutnya, dilakukan dengan cara yang sama dengan menghilangkan bit yang telah diproses sebelumnya, sehingga dihasilkan string akhir menjadi NAMA SAYA DIAN PRATIWI SAYA TINGGAL DI LUBUK PAKAM. Hasil dekompresi akan dijadikan menjadi file teks dan disimpan ke dalam media penyimpanan dengan format (*.rtf)

\section{IMPLEMENTASI}

Implementasi proses perbandingan kinerja dua algoritma ini terhadap proses kompresi file teks berformat rtf, dilakukan dengan membangun aplikasi menggunakan bahasa pemrograman visual basic net 2008.

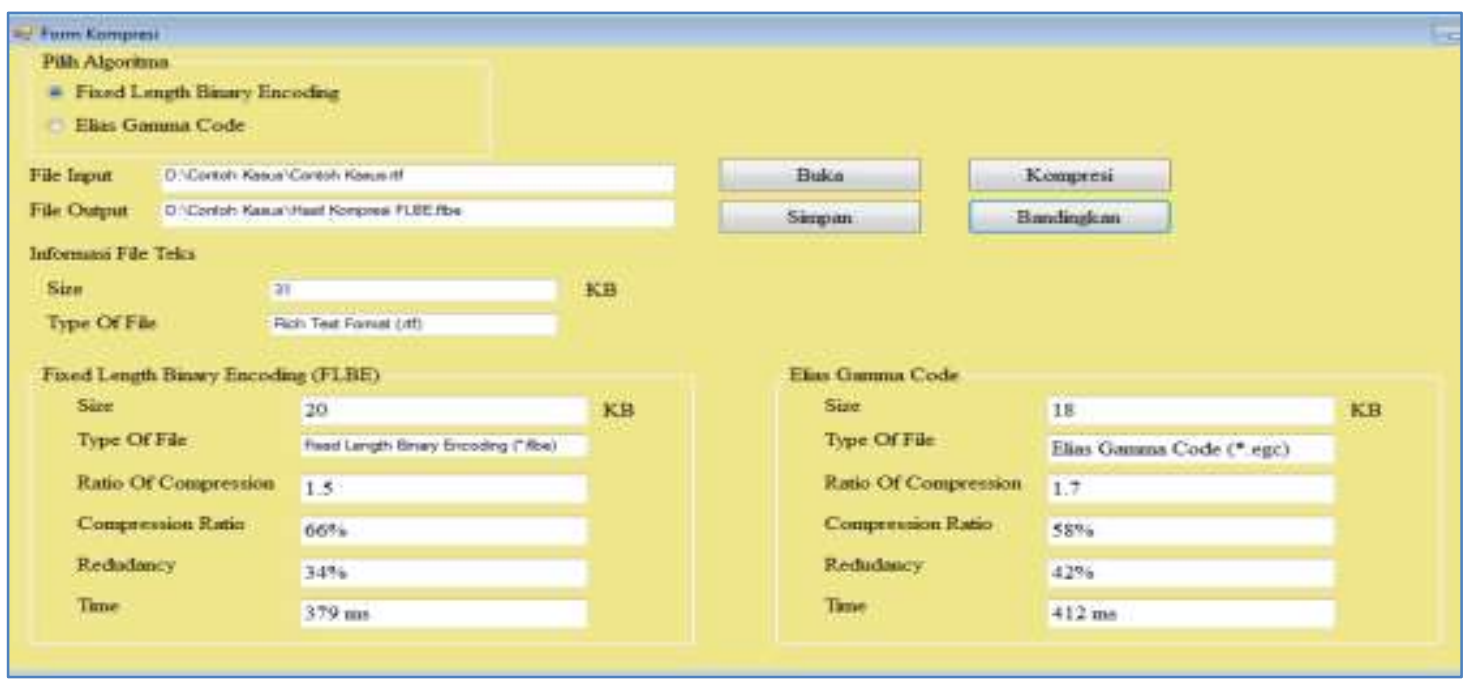

Gambar 1. Form Kompresi

Berdasarkan pengujian yang dilakukan, maka diperoleh hasil perbandingan kinerja antara algoritma FLBE dan elias gamma code sebagai berikut:

Tabel 4. Hasil Perbandingan

\begin{tabular}{|c|c|c|c|c|c|c|c|c|c|c|c|}
\hline \multirow{3}{*}{ No } & \multirow{3}{*}{$\begin{array}{c}\text { Size Awal } \\
\text { dari File }\end{array}$} & \multirow{2}{*}{\multicolumn{4}{|c|}{$\begin{array}{c}\text { Sebelum Kompresi } \\
\text { Fixed Length Binary } \\
\text { Encoding }\end{array}$}} & \multicolumn{6}{|c|}{ Setelah Kompresi } \\
\hline & & & & & & \multicolumn{6}{|c|}{ Elias Gamma Code } \\
\hline & & $\begin{array}{l}\mathrm{RC} \\
\text { (Bit) }\end{array}$ & $\begin{array}{l}\text { CR } \\
(\%)\end{array}$ & $\begin{array}{l}\text { RD } \\
(\%)\end{array}$ & $\begin{array}{l}\text { Time } \\
(\mathrm{ms})\end{array}$ & $\begin{array}{c}\text { Size file } \\
\text { Terkompresi }\end{array}$ & $\begin{array}{c}\text { RC } \\
\text { (Bit) }\end{array}$ & $\begin{array}{l}\text { CR } \\
(\%) \\
\end{array}$ & $\begin{array}{l}\text { RD } \\
(\%)\end{array}$ & $\begin{array}{l}\text { Time } \\
(\mathrm{ms})\end{array}$ & $\begin{array}{c}\text { Size File } \\
\text { Terkompresi }\end{array}$ \\
\hline 1 & $31 \mathrm{~KB}$ & 1,5 & 66 & 34 & 12000 & $20 \mathrm{~KB}$ & 1,7 & 58 & 42 & 25000 & $18 \mathrm{~KB}$ \\
\hline 2 & 4,69 MB & 2 & 50 & 50 & 20000 & $2,34 \mathrm{MB}$ & 1,83 & 54,54 & 45,5 & 21000 & 2,55 MB \\
\hline 3 & $94,9 \mathrm{~KB}$ & 1,5 & 66,7 & 33,3 & 15000 & $63,29 \mathrm{~KB}$ & 1,35 & 74,07 & 25,93 & 16000 & $70 \mathrm{~KB}$ \\
\hline
\end{tabular}

Berdasarkan pada hasil pengujian pada tabel di atas, dapat diambil rata-rata Ratio of Compression, Compression Ratio dan Redudancy algoritma Fixed Length Binary Encoding dan Elias Gamma Code. Berikut ini rumus untuk mencari rata-rata Ratio of Compression, Compression Ratio dan Redudancy adalah sebagai berikut. Misalnya contoh perhitungan nilai rata-rata Ratio of Compression pada algoritma Fixed Length Binary Encoding

Nilai Rata - Rata Ratio of Compression $=\frac{\text { Jumlah Ratio Of Compression }}{\text { Banyak Ratio Of Compression }}$ 
Nilai Rata - Rata Ratio Of Compression $=\frac{1,5+2+1,5}{3}=1,66$

Tabel 5. Nilai Rata-rata Aspek RC, CR, Rd dan Time

\begin{tabular}{cclll}
\hline \multirow{2}{*}{ Algoritma } & \multicolumn{3}{c}{ Rata-Rata } \\
\cline { 2 - 5 } & $\begin{array}{c}\text { Ratio Of } \\
\text { Compression } \\
\text { (Bit) }\end{array}$ & $\begin{array}{c}\text { Compression } \\
\text { Ratio }\end{array}$ & Redudancy & Time (ms) \\
\hline FLBE & 1,66 & $60,9 \%$ & $39,1 \%$ & 16 \\
\hline
\end{tabular}

Berdasarkan pengujian di atas, maka terlihat bahwa ukuran file setelah dilakukan proses kompresi, sangat jauh berkurang dari ukuran sebelumnya, sehingga dapat meminimalkan penggunaan ruang penyimpanan yang besar.

\section{KESIMPULAN}

Berdasarkan analisa, pembahasan dan pengujian penelitian ini, maka disimpulkan bahwa :

1. Berdasarkan penerapan algoritma Fixed Length Binary Encoding dan Elias Gamma Code telah membuktikan bahwa suatu file teks yang memiliki ukuran besar dapat dikompres menjadi ukuran yang lebih kecil. Dalam proses kompresi algoritma Fixed Length Binary Encoding dan Elias Gamma Code dipengaruhi oleh jumlah variasi karakter dan jumlah frekuensi tiap karakter. Berdasarkan dari hasil pengujian terhadap sistem bahwa ukuran file teks lebih kecil setelah dilakukan kompresi.

2. Berdasarkan perbandingan kinerja untuk mengkompresi file jenis (*.rtf) bahwa secara rata- rata algoritma Fixed Length Binary Encoding menghasilkan Ratio Of Compression yang terbaik yaitu 1,66 bit, diikuti akgoritma Elias Gamma Code yaitu sebesar 1,62 bit. Secara rata-rata algoritma Fixed Length Binary Encoding menghasilkan Compression Ratio yang terbaik yaitu 60,9\%, diikuti akgoritma Elias Gamma Code yaitu sebesar 62,20\%. Secara rata-rata algoritma Fixed Length Binary Encoding menghasilkan Redudancy yang terbaik yaitu 39,1\%, diikuti akgoritma Elias Gamma Code yaitu sebesar 37,79\%. Secara rata-rata algoritma Fixed Length Binary Encoding menghasilkan Time yang terbaik yaitu $16 \mathrm{~ms}$, diikuti akgoritma Elias Gamma Code yaitu sebesar $21 \mathrm{~ms}$. Hasil perbandingan kinerja antara algoritma Fixed Length Binary Encoding dan Elias Gamma Code dalam melakukan proses kompresi bahwa algoritma Fixed Length Binary Encoding lebih baik dari pada algoritma Elias Gamma Code.

3. Aplikasi kompresi yang dibangun dapat mempermudah pengguna untuk menurunkan ukuran data yang besar serta dapat memberikan informasi tingkat performa antara kedua algoritma yang digunakan.

\section{REFERENCES}

[1] F. Gram et al., “Analisis Perbandingan Kompresi dan Dekompresi Menggunakan Algoritma Shannon-," vol. 3, no. 3, pp. 5197-5204, 2016.

[2] A. Huffman, L. Z. W. D. A. N. Dmc, and N. J. Tuturoong, "Perbandingan rasio dan kecepatan kompresi menggunakan algoritma huffman, lzw dan dmc," vol. 08, no. 53, pp. 18-31, 2010.

[3] R. D. Pratiwi and S. D. Nasution, "PERANCANGAN APLIKASI KOMPRESI FILE TEKS DENGAN MENERAPKAN ALGORTIMA FIXED LENGTH BINARY ENCODING ( FLBE ),” vol. 2, no. 1, pp. 10-14, 2018.

[4] D. A. Yansyah, "PERBANDINGAN METODE PUNCTURED ELIAS CODE DAN HUFFMAN PADA KOMPRESI FILE TEKS," vol. 2, no. 6, pp. 33-36, 2015.

[5] Sukiman and T. Chandra, “Aplikasi Kompresi File dengan Algoritma Elias Gamma, ”Jurnal CORE IT, vol 1, no. 1, pp. 3948, 2013.

[6] S. David and G. Motta, Handbook Of Data Compression, 5th ed. London: Springer, 2010. 